\title{
Linguistic and Cultural Asymmetry in Translation from and into Minor Languages ${ }^{1}$
}

\author{
Kinga Klaudy \\ ELTE University, Budapest, Hungary
}

\begin{abstract}
The aim of the paper is to extend the asymmetry hypothesis (AH) to include cultural asymmetry between translation from a major into a minor language and vica versa, and to relate the AH to the domestication/foreignization dichotomy (Venuti 2005). In this paper the "minor" language is Hungarian in comparison with Russian and English as "major" languages. The asymmetry hypothesis (Klaudy 2001, 2009) assumes that explicitation and implicitation are not symmetric strategies, as translators, if they have a choice, tend to use the operations involving explicitation rather than operations involving implicitation. The paper concludes that domestication and foreignization are also asymmetric operations; while translators prefer explicitation on the linguistic level, on the cultural level translators seem to prefer domestication.
\end{abstract}

\section{The asymmetry hypothesis}

The asymmetry hypothesis was formulated in Klaudy (2001), further developed in Klaudy (2009) tested against data in Klaudy and Károly (2004, 2005, 2007) and Becher (2010). The hypothesis claims that in bidirectional translation analysis explicitation and implicitation are not always symmetric operations, as translators, when they have a choice, prefer operations involving explicitation

1 First published: Klaudy K. 2012. Linguistic and Cultural Asymmetry in Translation from and into Minor Languages. In: Kemppanen, H., Janis, M., Belikova A. (eds) Domestication and Foreignisation inTranslation Studies. Berlin: Franke und Timme. 33-49. 
(concretization of meaning, division of meaning, addition of meaning, grammatical concretization, grammatical addition, upgrading of noun phrases and participial phrases into clauses), and often fail to perform operations involving implicitation (generalization of meaning, contraction of meanings, omission of meaning, grammatical generalization, grammatical omission, downgrading of clauses into noun phrases or participial phrases).

The concept of interlanguage asymmetry was introduced into translation research by the Russian scholar Gak:

In translation confrontation takes place between units of two different languages. These units can be of two types in their relationship to each other. (1) Isomorphous units have identical meaning or are characterized by identical positions in the corresponding language systems. [...] Allomorpous units do not correspond to systemic equivalents in the other language. (Gak in Zlateva 1993:33)

According to Gak, isomorphous units in interlanguage are in a symmetric relationship, while allomorphous units are in an asymmetric relationship. Since Gak relates the concept of symmetry and asymmetry to language systems, his approach can be called static. In adapting the asymmetry hypothesis for translation, Klaudy (2009) takes a dynamic approach, relating the concept of symmetry and asymmetry to transfer operations.

According to Klaudy (2009) operational symmetry occurs when explicitation in one direction is paralleled by implicitation in the opposite direction. For example, specification of personal pronouns in the Hungarian-Russian direction is paralleled, or at least may be expected to parallel generalization of personal pronouns in the Russian-Hungarian direction.

(1) Hungarian ST-Russian TT (specification of personal pronouns):

Fügét is vett, mazsolát is vett. Mélyhűtött őszibarackot és málnát is vett. Be volt rúgva. (Örkény 59) (lit: Ø Bought also figs, Ø bought also raisins. $\varnothing$ Bought also deep-frozen peaches and raspberries. $\varnothing$ Was intoxicated.)

Он купил фиги. И изюм. И свеже-мороженные персики, и малину. Он опянем от покупок. (Voronkina 286) (lit: He bought also figs, bought also raisins. Bought also deep-frozen peaches and raspberries. He was intoxicated by shopping.)

(2) Russian ST- Hungarian TT (generalization of personal pronouns): 
Весь вечер он (...) думах об одном, как бы одну увидеть ёё, но она избегама его.(L. Tolstoy 68) (lit: All night he was thinking of her, how to meet her, but she escaped the encounter.)

Egész este (...) egyre csak leste az alkalmat, hogy négyszemközt találkozhasson vele, de ő elkerülte. (Szőllősy 71) (lit: All night $\varnothing$ was looking for the opportunity to meet $\varnothing$, but $\mathbf{s} /$ he escaped the encounter.)

On the other hand, operational asymmetry occurs when explicitation in one direction is not paralleled by implicitation in the opposite direction. E.g.: upgrading of phrases into clauses in the English-Hungarian direction is not paralleled by downgrading of clauses into phrases in the HungarianEnglish direction.

\section{Two methods of investigating operational asymmetry}

Operational asymmetry can be investigated by two-way comparisons of translated texts. Bidirectional comparison can be independent or not-independent. Independent bidirectional comparison is based on translations from L1 into L2 and from L2 into L1 produced independently from each other. Klaudy (2007), for example, investigated Hungarian translations of Russian authors (Tolstoy, Chekhov, Dostoyevsky, Bulgakov, Trifonov) and Russian translations of Hungarian authors (Jókai, Mikszáth, Móricz, Déry, Sarkady) and found that translators specify reporting verbs in translating from Russian into Hungarian, but fail to generalise reporting verbs in translating from Hungarian into Russian. The same results were obtained by Klaudy and Károly (2005) in a study of reporting verbs in Orwell's 1984 translated from English Hungarian and in Kosztolányi's Anna Édes translated form Hungarian into English.

The other method of investigating the $\mathrm{AH}$ is non-independent bidirectional comparison (back-translation), when we investigate translations from L1 into L2 and back-translations of the same text from L2 into L1. Klaudy (1996), for example, investigated additions in a speech by Árpád Göncz, former President of Hungary translated into English and back-translated into Hungarian. She found that items inserted in the Hungarian-English translation were retained in the English-Hungarian back-translation "even in cases where they could or should have been omitted” (Klaudy 1996:110).

Transfer operations can be divided into language specific and non languagespecific operations. Language specific operations can be obligatory in both directions, 
obligatory in only one direction or optional in both directions. AH research is interested in the two latter types because in these cases translators have a choice, and since choices are not entirely subjective, linguistic explanations can be offered for them.

\section{Linguistic asymmetry - previous research}

\subsection{Asymmetry between specification and generalization of repor- ting verbs}

Specification of reporting verbs is a standard transfer operation in RussianHungarian (RU-HU) and English-Hungarian (EN-HU) translation. Generalization of reporting verbs is a standard transfer operation in Hungarian- English (HU-EN) and Hungarian-Russian (HU-RU) direction. Both operations are optional. Studies by Klaudy (2007) and Klaudy and Károly (2005) claim that while translators do perform specifications in the RU-HU and the EN-HU direction, they fail to perform generalizations in the opposite direction. The reason for the specification of reporting verbs in the EN-HU and the RU-HU direction lies in the differences between literary traditions: while Russian and English authors prefer to use the central verb of the semantic field of reporting, i.e. сказаmъ and say respectively, Hungarian authors opt for more peripheral verbs, and use a large variety of more specific verbs for reporting. Table 1 compares reporting verbs in literary works by Russian and Hungarian authors. As we can see from the Table, 100 Russian reporting verbs include 16 types in Tolstoy's, 21 types in Dostoyevsky's and 24 types in Chekhov's works. The reporting verbs used by Hungarian authors show a greater variety in 100 verbs, there are 36 types in Jókai's, 53 in Mikszáth’s, and 35 in Móricz's works.

\section{Table 1}

Variability of reporting verbs in original RU and HU works

\begin{tabular}{|l|c|c|c|}
\hline & Token & Type & Type/token \\
\hline Tolstoy & 100 & 16 & 0.16 \\
\hline Dostoyevsky & 100 & 21 & 0.21 \\
\hline Chekhov & 100 & 24 & 0.24 \\
\hline Jókai & 100 & 36 & 0.36 \\
\hline Mikszáth & 100 & 53 & 0.53 \\
\hline Móricz & 100 & 35 & 0.35 \\
\hline
\end{tabular}


The translation of reporting verbs was analyzed for specification or generalization in 800 sentences. 400 sentences were drawn from original texts: (1) Anna Karenina by Tolstoy, (2) 1984 by Orwell, (3) Szent Péter esernyöje by Mikszáth, and (4) Édes Anna by Kosztolányi. The other 400 sentences were drawn from their translations.

\section{Table 2}

Specification of reporting verbs in RU-HU translation

\begin{tabular}{|l|c|l|c|}
\hline $\begin{array}{l}\text { Russian original } \\
\text { Tolstoy, L.N. } \\
\text { Anna Karenina }\end{array}$ & $\begin{array}{c}\text { Frequency } \\
\text { of verbs }\end{array}$ & $\begin{array}{l}\text { Hungarian translation } \\
\text { Translated by Klára Szőllösy }\end{array}$ & $\begin{array}{c}\text { Frequency } \\
\text { of verbs }\end{array}$ \\
\hline 1. сказать ('say') & 55 & 1. mond ('say') & 37 \\
\hline $\begin{array}{l}\text { 2. проговорить } \\
\text { ('begin to speak') }\end{array}$ & 10 & 2. kérdez ('ask') & 11 \\
\hline 3. отвечать ('answer') & 6 & 3. felel ('answer') & 10 \\
\hline 4. спросить ('ask') & 6 & 4. szól ('utter') & 5 \\
\hline 5. Аумать ('think') & 5 & 5. válaszol ('answer') & 5 \\
\hline 6. прибавить ('add') & 4 & 6. hozzátesz ('add') & 4 \\
\hline 7. говорить ('talk') & 2 & 7. gondol ('think') & 3 \\
\hline 8. повторить ('repeat') & 2 & 8. ismétel ('repeat') & 3 \\
\hline 9. послыхать ('perceive') & 2 & 9. kezd ('begin') & 3 \\
\hline 10. продомжать ('continue') & 2 & 10. folytat ('continue') & 2 \\
\hline 11- 17. = verbs occuring once & 6 & 11. sóhajt ('sigh') & 2 \\
\hline & & 12. kiált ('shout') & 11 \\
\hline
\end{tabular}




\section{Table 3}

Specification of reporting verbs in EN-HU translation

\begin{tabular}{|c|c|c|c|}
\hline $\begin{array}{l}\text { English original } \\
\text { Orwell, G. Nineteen } \\
\text { Eighty-Four. }\end{array}$ & $\begin{array}{c}\text { Frequency } \\
\text { of verbs }\end{array}$ & $\begin{array}{l}\text { Hungarian translation } \\
\text { Translated by Szíjgyártó } \\
\text { László }\end{array}$ & $\begin{array}{c}\text { Frequency } \\
\text { of verbs }\end{array}$ \\
\hline 1. say & 79 & 1. felel ('answer') & 18 \\
\hline 2. whisper & 4 & 2. kérdez ('ask') & 14 \\
\hline 3. murmur & 3 & 3. megállapít ('remark') & 10 \\
\hline 4. add & 2 & 4. kijelent ('state') & 10 \\
\hline 5. yell & 2 & 5. mond ('say') & 4 \\
\hline 6. begin & 2 & 6. kezd ('begin') & 4 \\
\hline 7. agree & 2 & 7. megjegyez ('comment') & 4 \\
\hline \multirow[t]{8}{*}{ 8-14. = verbs occuring once: } & 7 & 8. megszólal ('say/utter') & 3 \\
\hline & & 9. kiált ('shout') & 3 \\
\hline & & 10. mormol ('murmur') & 3 \\
\hline & & 11. suttog ('whisper') & 3 \\
\hline & & 12. közöl ('tell') & 2 \\
\hline & & 13. hozzátesz ('add') & 2 \\
\hline & & 14. folytat ('continue') & 2 \\
\hline & & $15-32 .=$ verbs occuring once & 18 \\
\hline Total & 100 & Total & 100 \\
\hline
\end{tabular}

As Table 2 shows, the 100 reporting verbs (token) of the Russian source text consist of 17 different reporting verbs (type), while the 100 reporting verbs (token) of the Hungarian target text contains 23 different reporting verbs (type). As Table 3 shows, English source text consist of 14 different reporting verbs (type), while the 100 reporting verbs (token) of the Hungarian target text contains 32 different reporting verbs (type) The increasing type/token ratios $(0.17<0.23$. and $0.14<0.32$ ) indicate that the Hungarian translators used more specific verbs than the author of the source text, i.e., resorted to the explicitation of the meaning implied in the Russian and English original.

As authors of original English texts prefer to use the central verbs of the semantic field of verbs of saying, the number of different verbs should have been decreased in the English translation of the Hungarian novel. This, however, did not happen. 


\section{Table 4.}

Unperformed generalization of reporting verbs in the HU-EN direction

\begin{tabular}{|c|c|c|c|}
\hline & $\begin{array}{c}\text { Total No. } \\
\text { of verbs }\end{array}$ & $\begin{array}{c}\text { No. of } \\
\text { different } \\
\text { verbs }\end{array}$ & Type/token \\
\hline Édes Anna (HU) & 100 & 56 & 0.56 \\
\hline Anna Édes (EN) & 100 & 56 & 0.56 \\
\hline Szent Péter... (HU) & 100 & 27 & 0.27 \\
\hline St. Peter's... (EN) & 100 & 24 & 0.24 \\
\hline
\end{tabular}

As we can see from Table 4, the diversity of Hungarian reporting verbs is preserved in the English translation: the translator did not generalise reporting verbs to bring them into line with English literary tradition. The type-token ratio in Anna Édes, the English translation of Kosztolányi's work, remains just as high as in the ST (0.56). St. Peter's Umbrella, the English translation of Mikszáth's Szent Péter esernyöje, shows a minimal decrease, from 0.27 to 0.24 .

The data presented above lend support for the asymmetry hypothesis: semantic specification of reporting verbs (explicitation) was performed in translating from Russian and English into Hungarian, but semantic generalization was not performed in the opposite direction.

\subsection{Asymmetry between addition and omission of extra categories}

In another attempt to verify the $\mathrm{AH}$, grammatical additions and omissions were studied by Klaudy and Károly (2004). These standard transfer operations are motivated by systemic differences between languages, and thus they appear to be obligatory in both directions. Grammatical addition is a standard transfer operation whereby grammatical (functional) elements that are not present in the SL text must be inserted into the TL text. Grammatical omission is a standard transfer operation whereby certain grammatical (functional) elements present in the SL text, being redundant in the TL, will not appear in the TL text. The systemic reason behind these operations is the phenomenon of so called missing categories: certain grammatical categories (gender, number, case, article, prepositions, postpositions, verbal prefixes, separable verbal prefixes, definite conjugation) may exist in one language, but not in the other. If we translate into a TL 
language that has one of these "extra" categories compared to the SL, additions will appear. Conversely, in translating into a TL in which, compared to the SL, a category is missing, omissions will occur. Addition and omission of articles, e.g., are symmetric operations in RU-HU and HU-RU translation, since there is no article in Russian. Another reason for grammatical addition and omission may be that, although a particular grammatical category does exist in both languages (e.g., the personal pronoun in both English and Hungarian), its functions are different, and its use is governed by different rules govern in the two languages. Functional differences can make additions obligatory in one direction, while in the other direction omission is optional. Addition of the indefinite article, pronominal subjects and objects, personal or posessive pronouns is obligatory in HU-EN translation. However, omission of the same categories is optional in EN-HU translation, and our experience in editing translations showed that optional omission was not always practized by translators. To confirm this observation, a small corpus was compiled, consisting of 100 sentences from Orwell's 1984 translated from English into Hungarian and 100 sentences from Mikszáth's St Peter's Umbrella translated from Hungarian into English.

\section{Table 5.}

Unperformed omission of extra categories in the EN-HU direction

\begin{tabular}{|l|c|c|c|}
\hline & $\begin{array}{c}\text { Obligatory } \\
\text { additions } \\
\text { HU-EN }\end{array}$ & $\begin{array}{c}\text { Optional } \\
\text { omissions } \\
\text { EN- HU }\end{array}$ & $\begin{array}{c}\text { Unperformed } \\
\text { omissions } \\
\text { EN-HU }\end{array}$ \\
\hline Subject & 50 & 47 & 7 \\
\hline Indefinite article & 16 & 10 & 16 \\
\hline $\begin{array}{l}\text { Pronominal subjects } \\
\text { and objects }\end{array}$ & 5 & 7 & 3 \\
\hline Possessive determiner & 25 & 20 & 2 \\
\hline Total in 100 sentences & 96 & 84 & 28 \\
\hline
\end{tabular}

As is shown in Table 5, while the translators did perform addition (explicitation) in the HU-EN direction, they failed to perform omission (implicitation) in the EN-HU direction. Unperformed omissions of extra categories, e.g. retention of unnecessary indefinite articles in the Hungarian translations are unmistakable signs of SL influence (cf. translationese). 
The asymmetry hypothesis was studied by Becher (2011) to elucidate the asymmetric relationship between addition and omission of connectives. His bidirectional parallel corpus consists of German business texts translated into English and English business texts translated into German (ca. 80000 words). In this corpus he counted (manually) 114 additions of connectives in the EN-DE translation and 48 additions in the DE-EN translation, 32 omissions of connectives in EN-DE translation and 51 omissions in DE-EN translation. He concluded that German texts exhibit more additions and fewer omissions of connectives than the English target texts. Speakers of German tend towards a greater degree of cohesive explicitness than speakers of English. According to these data explicitations are not counterbalanced by implicitations, ie. "the quantitative results confirm the Asymmetry Hypothesis for this data set” (Becher 2011:31).

\section{Extending the asymmetry hypothesis to the cultural level}

In the second part of this paper the concept of operational asymmetry in translation will be related to the domestication/ foreignization dichotomy in research of translation from and into minor languages. The terms domestication and foreignization were introduced by Venuti in 1995. Domestication means translation strategies which result in transparent, natural-sounding, fluent TL style, minimize the strangeness of TT by the removal of SL realia, and require less effort on the part of the receptor.

Foreignization means using translation strategies which retain the foreign flavour of the original. Foreignization, which results in a non-fluent style, deliberate breaking of TL conventions and retention of SL realia in the TL text, requires more effort on the part of the receptor.

The question is whether the explicitation/implicitation asymmetry has a connection with domestication/ foreignization strategies, and how it is influenced by the minor/major status of the two languages. In this paper the "minor" language is Hungarian in comparison with Russian and English as "major" languages. It can be assumed that domestication characterizes translation from less widely spoken languages into more widely spoken languages, e.g., from Hungarian into Russian or English, and foreignization characterizes translations from more widely spoken languages into less widely spoken languages, e.g., from Russian or English into Hungarian. If domestication in one direction (from minor into major) is paralleled by foreignization in the other direction (from major into minor), the relationship can be regarded as symmetric, if domestication in one direction (from minor into 
major) is not paralleled by foreignization in the other direction (from major into minor), the relationship can be regarded as asymmetric.

In the following we will compare four languages and cultures: English, Russian, Hungarian and Finnish from three points of view: (1) minor or major status of the languages under study, (2) linguistic relatedness, and (3) cultural closeness. (Further research did not include Finnish language texts.)

\subsection{Minor or major languages, closeness of languages and cultures}

The minor or major status of a language can be defined from different angles. English is spoken by 341 million speakers. It is spoken as a native language on four continents. Russian is spoken by 167 million speakers and is spoken as a native language on two continents. Hungarian is spoken by 14 million speakers and it is spoken as a native language in Europe only, and Finnish is spoken by 7 million speakers and it is spoken as a native language in Europe only. On the basis of the above we can class English and Russian as more widely spoken languages, while Hungarian and Finnish must be regarded as less widely spoken languages.

As for linguistic relatedness, English and Russian belong to the IndoEuropean language family. Finnish and Hungarian belong to the family of Uralic languages.

In 1964 Nida proposed a typology of different combinations of linguistic and cultural relatedness. He distinguished three frequent types: (1) closely related languages and close cultures (e.g., Hebrew and Arabic), (2) close cultures and non-related languages (e.g., Swedish and Finnish), (3) distant languages, distant cultures (e.g., English and Zulu), and a rare case: (4) distant cultures and cognate languages (e.g., Hindi and English). According to Nida's typology, our language pairs can be characterised in the following way:

1. Hungarian and Finnish $=$ Close cultures and related languages

2. English and Russian $=$ Close cultures and related languages

3. English and Hungarian $=$ Close cultures and non related languages

4. Russian and Hungarian $=$ Close cultures and non related languages

Cultural closeness, of course, has to be substantially refined taking into consideration proximity factors and distancing factors such as religion, geography, climate, density of population etc. Among the proximity factors we have to men- 
tion first Christianity, which characterizes all the four cultures. As for distancing factors, closeness to the sea and experience in navigation have played an important role in English, Russian and Finnish culture, but not so in Hungarian culture. Long winters have left their imprint on Russian and Finnish culture, but less so on English and Hungarian culture. Russians and Hungarians had experience of totalitarian regimes in the recent past, while English and Finnish people did not have this experience. Population density in England and Hungary is relatively high, so these nations do not share the experience wide open spaces with people living in Russia and Finland.

All these factors heavily influence translators' work, as Nida stated: “[...] differences between cultures cause many more severe complications for the translator than do differences in language structure" (Nida 1964:161).

\subsection{Relationship between cultural differences and cultural asymmetry}

Cultural differences are not equal to cultural asymmetry. Cultural asymmetry means first of all three things: (1) one-way traffic in the information channels between cultures (2) one of the cultures is emissive (where 'emissive' means having a power to emit and distribute widely its own cultural achievements), the other is receptive (where 'receptive' means willingness to internalize other people's cultural achievements and of course does not mean lack of originality and creativity); (3) information flows from more widely spoken languages to less widely spoken languages.

It may be assumed that translation from less widely spoken languages into more widely spoken languages (from Hungarian into Russian or English) involves domestication, and translation from more widely spoken languages into less widely spoken languages (from English and Russian into Hungarian) involves foreignization. The supposed reason for the domestication from minor into major is the following: due to the limited knowledge of the target audience about the source culture, the translator has to make an extra effort to be understood. The supposed reason for foreignization from major into minor is that the main function of translation from more widely spoken languages is to widen the conceptual and cultural horizon of the target audience, to introduce new ideas and new concepts into the target culture, which necessarily means the introduction of SL concepts and words into the target text. 
Let us see some examples of foreignization occurring in translation from a widely spoken language, such as English and Russian into a less widely spoken language, such as Hungarian:

- In the 20th century, before World War II, the use of Russian words in the translation of Russian classics into Hungarian had the function of creating atmosphere;

- In the 20th century, after World War II, the use of Russian words in Hungarian political language characterized the ,insider” talk of Hungarian political leaders;

- At the beginning of the 21st century, the use of English words in journalistic and scientific Hungarian texts is a consequence of globalization and the development of information technology.

Let us see examples of domestication occurring in translation from Hungarian as a less widely spoken language into more widely spoken languages like English or Russian. We collected examples for one of the domesticating strategies, namely removal in the target text of SL realia (archaisms, Latinisms, units of measurements etc.).

Removal of SL archaisms in HU-EN, HU-RU translation

(3) Hungarian ST: Ebéd után csibukra gyújtott a várúr ... (Mikszáth 15)

(3a) English TT: After lunch the count lit up his pipe ... (Sturgess 17)

(3b) Russian TT: После обеда хозяин закуривал трубку ... (Leybutin 18) (lit: After lunch the host lit his pipe)

In example (3), the connotations of csibuk ('pipe'), connected with its archaic flavour, are not rendered in the translations.

Removal of SL units of measurement in HU-EN translation

(4) Hungarian ST: Azt üzente Cseténé, hogy hozzon egy kiló kenyeret és húsz deka felvágottat. (Örkény 1. 55)

(4a) English TT: That's why she asked Mrs Csete to tell Kopp to take home a loaf of bread and some cold cuts. (Sollosy 50) 
In example (4), the connotations of kiló and búsz deka ('kilo', 'twenty decagrams'), the usual units of measurement used in talking about weights of groceries in Hungary, are not rendered in the translations.

Removal of Latinisms in HU-EN, HU-RU translation

(5) Hungarian ST: A vitalicumot félévenként kapták ... (Mikszáth 20).

(5a) English TT: This income was paid every six months ... (Sturgess 23)

(5b) Russian TT: Аенги выплачивались баронам дважди в год. (Leybutin

24) (The money was paid to barons two times a year.)

In example (5), the word vitalicum is probably not known by present-day Hungarian readers, but it is recognized as a Latin word used by many educated people in Mikszáth's time. These connotations are lost in the translations.

At the beginning of this chapter (4.2.) we assumed that domestication characterizes translation from less widely spoken languages into more widely spoken languages, e.g. from Hungarian into Russian or English, and foreignization characterizes translations from more widely spoken languages into less widely spoken languages, e.g. from Russian or English into Hungarian. Based on our analysis of cca. 200 book-length translations (mainly of literary works) from English, German, French and Russian into Hungarian, and 200 translations in the opposite direction (Klaudy 2003), we claim that all the above mentioned types of domestications can also be found in the opposite direction, that is, in translations from more widely spoken into less widely spoken languages.

(6) English ST: ... as he had never worked with Carter Paterson and was unused to such exertions, ... (Durrell 62)

(6a ) Hungarian TT: ... Soha nem dolgozott a bútorszállító szakmában, nem szokott efféle erőmutaványokhoz, ... (Sárközi 64)

In example (6) The English trade name, which is, the name of the company Carter Paterson, was left out from the Hungarian translation and instead we find the general name of the activity carried on by the company: bútorszállitó sqakma ('furniture removal business').

(7) English ST: He was alone in the great Belgravia house with Baines and Mrs Baines. (Greene 457) 
(7a) Hungarian TT: ... így egyedül maradt a nagy házban Baines-szel és a feleségével. (Szobotka 280)

In example (7), the name of Belgravia, a reference to the characters' social status, is omitted and replaced by the much weaker innuendo of nagy hár. ('great house')

If domestication in one direction (from minor into major) is not paralleled by foreignization in the other direction (from major into minor), the relationship between domestication and foreignization can be regarded as asymmetric. Thus, the asymmetry hypothesis, which claims that translators, given a choice, tend to use operations involving explicitation rather than operations involving implicitations, can be extended from the linguistic level to the cultural level: translators, given the choice, tend to adopt domesticating rather than foreignizing strategies.

The domestication/foreignization dichotomy is probably not applicable to language pairs in their totality, but it is a good starting point for research if we want to investigate the proportion of domesticating and foreignizing strategies in different literary periods, different genres (literary translation, audiovisual translation), in the solution of specific translation problems (translation of film titles, translation of proper names etc.), or in the individual style of translators.

\subsection{Conclusion}

The aim of this paper was no more than to think over the relationship between the asymmetry hypothesis and the domestication/foreignization dichotomy. Asymmetry hypothesis extended to the cultural level (which would be worth examining in the future on large bidirectional databases of different language pairs) can be summarized in the following two points: (1) Domestication and foreignization are not symmetric operations: we cannot claim that domestication in one direction (from minor to major) is necessarily complemented by foreignization in the opposite direction (from major to minor). (2) While translators prefer explicitation on the linguistic level, on the cultural level translators seem to prefer domestication. 


\section{References}

BECHER, Viktor. When and why translators add connectives? A corpus based study. In: Target 23 (1), 2011, p. 26-47.

GAK, V. Interlanguage asymmetry and the prognostication of transformations in translation. In: Zlateva, Palma (ed.): Translation as Social Action. London: Routledge, 1993, p. 32-39.

KLAudy, Kinga. Back Translation as a Tool for Detecting Explicitation Strategies in Translation." In: Klaudy, Kinga/ Lambert, José/ Sohár, Anikó. (eds.): Translation Studies in Hungary. Budapest: Scholastica, 1996, p. 99-114.

KLAudy, Kinga. The Asymmetry Hypothesis. Testing the Asymmetric Relationship between Explicitations and Implicitations. Paper presented at the Third International Congress of the European Society for Translation Studies, Claims, Changes and Challenges in Translation Studies, Copenhagen, 2001, August-30 and September 1.

KLAudy, Kinga. Languages in Translation. Lectures on the Theory, Teaching and Practice of Translation. With Illustrations in English, French, German, Russian and Hungarian. Budapest: Scholastica, 2003.

KuAudy, Kinga; Károly, Krisztina. Unperformed Omissions in Translation - The Asymmetry Hypothesis Further Developed. A paper presented at the Fourth International Congress of the European Society for Translation Studies, Doubts and Directions in Translation Studies, Lisbon, 2004, September 2-4.

KLAUDY, Kinga; KÁROLY, Krisztina. Implicitation in Translation: Empirical Evidence for Operational Asymmetry in Translation. In: Across Languages and Cultures 6 (1). 2005, p. 13-28.

Kuaudy, Kinga; Károly, Krisztina. The Asymmetry Hypothesis Further Developed: the Asymmetry of Upgrading and Downgrading in Translation. Paper presented at the Fifth International Congress of the European Society for Translation Studies, Why Translation Studies Matters. Ljubljana, 2007, September 3-5.

KLAudy, Kinga. Nyelv és fordítás [Language and Translation]. Budapest: Scholastica, 2007. (in Hungarian).

KLAudy, Kinga. The Asymmetry Hypothesis in Translation Research. In: Dimitriu, Rodica; Shlesinger, Miriam (eds): Translators and their readers. In Homage to Eugene A. Nida. Brussels: Les Editions du Hazard, 2009, p. 283-303.

NIDA, Eugene A. Toward a science of translating. Leiden: Brill, 1964.

VEnuti, Lawrence. The translators's invisibility. A history of translation. London and New York: Routledge. 1995. 


\section{Sources}

Durrell, Gerald. My Family and Other Animals. London: Penguin Books, 1963. . Családom és egyéb állatfajták. Trans. by Sárközi Györgyné. Budapest: Európa. 1966.

Greene, Graham. Collected Stories. London: The Bodley Head, 1972. . Válogatott elbesqélések. Trans. by Szobotka Tibor. Budapest: Európa, 1974.

Kosztolányi, Dezső. Édes Anna. Budapest: Szépirodalmi Kiadó, 1988. - Anna Édes. Trans. into English by George Szirtes. Budapest: Corvina, 1991.

Mikszáth, Kálmán. Szent Péter esernyöje. Budapest: Akadémiai Kiadó. 1957 . St Peter's Umbrella. Trans. into English by B. W. Worswick. Budapest: Corvina, 2002. Mikszáth, Kálmán. Besz̨terce ostroma. Budapest: Akadémiai Kiadó, 1957. The Siege of Beszterce. Trans. into English by Dick Sturgess. Budapest: Corvina, 1982.

Miksat, Kalman. Osada Bestertse. Translated by G. Leybutin. Budapest: Corvina, 1962.

Orwell, George. Nineteen Eighty-Four. London: Penguin Books, 1954. 1989. . 1984. Trans. into Hungarian by Szijgyártó László. Budapest: Európa Könyvkiadó,

ÖRKÉNY, István. Egyperces novellák. Budapest: Magvető, 1968.

. One Minute Stories. Trans. into English by Sollosy Judy. Sydney: Brandl and Schlesinger, 1994.

Tolstoy, L. N. Voskeresenie. Moscow: Sovremennik, 1977.

. Feltámadás. Trans. into Hungarian by Szőllősy Klára. Budapest: Európa, 1962.

Tolstoy, L. N. Anna Karenina. Leningrad: Lengiz, 1946.

- Anna Karenina. Trans. into Hungarian by Németh László. Bukarest: Kriterion, 1988. 